\title{
Effect of Cover Crop, Slurry Application with Different Loads and Tire Inflation Pressures on Tire Track Depth, Soil Penetration Resistance and Maize Yield
}

\author{
Gerhard Moitzi *(D), Elisabeth Sattler and Helmut Wagentristl \\ Department of Crop Sciences, Experimental Farm Groß-Enzersdorf, University of Natural Resources and \\ Life Sciences, Vienna (BOKU), Schloßhofer Straße 31, 2301 Groß-Enzersdorf, Austria; \\ elisabeth.sattler@students.boku.ac.at (E.S.); helmut.wagentristl@boku.ac.at (H.W.) \\ * Correspondence: gerhard.moitzi@boku.ac.at; Tel.: +43-676-9558336
}

check for updates

Citation: Moitzi, G.; Sattler, E.; Wagentristl, H. Effect of Cover Crop, Slurry Application with Different Loads and Tire Inflation Pressures on Tire Track Depth, Soil Penetration Resistance and Maize Yield. Agriculture 2021, 11, 641. https:/ / doi.org/10.3390/agriculture11070641

Academic Editors: Sara Marinari,

Roberto Mancinelli and

Emanuele Radicetti

Received: 2 June 2021

Accepted: 8 July 2021

Published: 8 July 2021

Publisher's Note: MDPI stays neutral with regard to jurisdictional claims in published maps and institutional affiliations.

Copyright: (c) 2021 by the authors. Licensee MDPI, Basel, Switzerland. This article is an open access article distributed under the terms and conditions of the Creative Commons Attribution (CC BY) license (https:// creativecommons.org/licenses/by/ $4.0 /)$.

\begin{abstract}
Agricultural soils can be affected in their ecological functions by in-field traffic of agricultural machinery. A three-factorial research design was carried out in a field experiment to test the effect of slurry tanker filling level (filled, half-filled, empty), tire inflation pressure of the slurry tanker (high: $300 \mathrm{kPa}$, low: $100 \mathrm{kPa}$ ), and ground covering (+cover crop, -cover crop) on tire track and soil penetration resistance (averaged, $0-20 \mathrm{~cm}, 21-40 \mathrm{~cm}$ ) after application on the fields in spring. Additionally, the effect on grain yield of the subsequent culture was considered. The total weight of the tractor slurry tanker combination was 16,470 kg (empty), 25,940 kg (half-filled), and 34,620 kg (filled). The low tire inflation pressure of the slurry tanker increased the mean tire-soil contact area by $75 \%$ (filled), 38\% (half-filled), and 16\% (empty tanker). The results obtained show a significant effect of tire inflation pressure and ground covering on the measured parameters. The tire inflation pressure reduction effect on track depth was highest in the filled slurry tanker $(-17.8 \%)$. With increasing wheel load, the effect of reduced tire inflation pressure on soil penetration resistance $(0-20 \mathrm{~cm})$ increased. In the subsoil $(21-40 \mathrm{~cm})$, the effect of tire inflation pressure was much lower, indicating that a reduction of tire inflation pressure preserves the upper layers rather than the lower ones. Furthermore, cover crops are linked to a higher degree of soil deformation after traffic with the tractor-slurry combination due to their loosening effect on the topsoil. Tire tracks were $15.0 \%$ deeper in the cover crop field than in the field without a cover crop. It is assumed that cover crop mixtures with different types of root mass can influence the mitigation of soil compaction in an ameliorative way.
\end{abstract}

Keywords: cover crop; slurry tanker; soil-tire contact area; soil penetration resistance; track depth; tire inflation pressure; wheel load

\section{Introduction}

Agricultural soils have a wide diversity of ecological services (e.g., root growth, water movement, aeration) that are directly influenced by the physical properties of soils [1] Farm vehicles should not impose stresses that exceed soil strength. Heavy agricultural vehicles passing on low load-bearing and soft soil (loosened, wet) can generate tire tracks in the field with potential risk of subsoil compaction.

Studies by Keller et al. [2] stated that future agricultural operations must consider inherent mechanical limits of soil due to increasing average weight of farm machinery exceeding loads bearable by the ground. The risk of soil compaction can be reduced by technical measurements with increased contact area between the soil and tire (e.g., controlling tires inflation pressure, traction devices with larger footprints, rubber tracks, additional axels/wheels) [1,3,4]. Furthermore, agronomical measures (e.g., diverse crop rotation, date of machinery operation, conservation tillage) can also raise the trafficability 
of the soil [5]. Tire inflation pressure and soil wetness during slurry spreading will affect the soil physical properties (penetration resistance, bulk density, and macro-porosity) [6].

SchjØnning et al. [7] found significant yield reductions due to repeated wheel passes (tractor-trailer combinations for slurry application), while single-pass treatment of a selfpropelled slurry application machine with $12 \mathrm{Mg}$ wheel load did not have significant effects on crop yield. In order to avoid subsoil compaction, they also suggested an upper threshold of $3 \mathrm{Mg}$ wheel load for highly inflated tires on a tractor-trailer combination during springtime.

Crop rotations that include tap-rooted species of cover crops may help alleviate the deleterious effects of soil compaction on plant growth by modifying the soil's physical properties [8]. The positive effect of cover crops on soil functions has been well studied [8,9], but not on the mitigation of soil compaction after the passing of farm machinery.

Slurry application with the tractor-tanker combination is commonly used in Austria. This study analyzed the effect of slurry application in spring with different loads and tire inflation pressures in a field without a cover crop and in a field with cover crop on track depth, soil penetration resistance, and grain yield of the subsequently grown maize.

\section{Materials and Methods}

\subsection{Experimental Site and Climatic Conditions}

The experiment was carried out on farm fields in the northern part of the Austrian province of Burgenland in Krensdorf $\left(47^{\circ} 80^{\prime} \mathrm{N}, 16^{\circ} 41^{\prime} \mathrm{E}, 194 \mathrm{~m}\right.$ a.s.l.). This province is part of the Pannonian Basin with Pannonian climate conditions. The mean annual precipitation in 2018 was $637 \mathrm{~mm}$ with a maximum rainfall of $79 \mathrm{~mm}$ in June and a minimum of $31 \mathrm{~mm}$ in January. The mean annual temperature was $9.7^{\circ} \mathrm{C}$ [10]. The soil of the field sites is classified as chernozem with an A-horizon depth between $37 \mathrm{~cm}$ and $46 \mathrm{~cm}$. The soil $(0-30 \mathrm{~cm})$ with $34 \%$ clay, $49 \%$ silt, and $17 \%$ sand is described as a loam with an soil organic carbon of $18.6 \mathrm{~g} \mathrm{~kg}^{-1}$.

\subsection{Experimental Design and Management}

The experiment with three slurry tanker filling levels and two tire inflation pressures of the tanker wheels (Table 1) was carried out on two adjacent fields (à 3 ha). In both fields, a crop rotation with maize (Zea mays), durum wheat (Triticum durum), sugar beet (Beta vulgaris), and winter wheat (Triticum aestivum) was established using a reduced tillage system (without moldboard plough). After the pre-crop of winter wheat, a freezekilled cover crop mixture $\left(3 \mathrm{~kg}^{-1}\right.$ phacelia-Phacelia tanacetifolia, $1 \mathrm{~kg} \mathrm{ha}^{-1}$ white mustard—Sinapis alba, $4 \mathrm{~kg} \mathrm{ha}^{-1}$ oil radish—Raphanus sativus, buckwheat-14.5 $\mathrm{kg} \mathrm{ha}^{-1}$ Fagopyrum esculentum) was sown in one field (+cover crop) on 30 September 2017. The second field was without a cover crop (-cover crop) and was bare during the winter period.

Application with the tractor-slurry tanker combination was conducted on 3 and 4 April 2018. The tire print of each tire of the tractor and slurry tanker was measured photometrically (Figure 1) according to Diserens et al. [11]. The average soil moisture content $(0-30 \mathrm{~cm})$ was $31.5 \%$ in the field with a cover crop and $28.4 \%$ in the field without a cover crop. The tractor slurry tanker combination was about $12 \mathrm{~m}$ in length and weighed $16,470 \mathrm{~kg}$ (empty), $25,940 \mathrm{~kg}$ (half-filled), and $34,620 \mathrm{~kg}$ (fully filled). The slurry tanker (Zunhammer SKE18500 PU, Germany) with tandem axles was equipped with a $15 \mathrm{~m}$ range drag shoe dispenser for slurry application and a single tube tire inflation pressure control system. The slurry tanker volume was $16,500 \mathrm{~L}$. The tire inflation pressure of the tractor was constantly at $150 \mathrm{kPa}$ in all four wheels, whereas for the slurry tanker tires, the inflation pressure was set at $300 \mathrm{kPa}$ (high) and at $100 \mathrm{kPa}$ (low), depending on the setting. The passing speed was set constant with $5.6 \mathrm{~km} \mathrm{~h}^{-1}$.

A randomized design with 18 blocks per field was applied to both fields (+cover crop, - cover crop). Each block measured $20 \mathrm{~m} \times 3 \mathrm{~m}, 30 \mathrm{~m}$ away from the next row, at a distance of $6 \mathrm{~m}$ to the next slot. These 18 blocks per field were divided into sections of three blocks each of which were treated as follows: high tire inflation pressure and filled slurry tanker 
treatment, high inflation pressure and half-filled slurry tanker, high inflation pressure and empty slurry tanker, low inflation pressure and filled slurry tanker, low inflation pressure and half-filled slurry tanker, and low inflation pressure and empty slurry tanker.

Table 1. Characteristics of the experimental design with technical parameters.

\begin{tabular}{|c|c|c|c|c|c|c|}
\hline \multirow[b]{2}{*}{ Tanker Filling Level } & \multirow[b]{2}{*}{ Wheel } & \multirow[b]{2}{*}{ Wheel Load ${ }^{4}(\mathrm{kN})$} & \multicolumn{2}{|c|}{ Tire-Soil Contact Area ${ }^{5}\left(\mathrm{~cm}^{2}\right)$} & \multicolumn{2}{|c|}{ Mean Ground Pressure (kPa) } \\
\hline & & & $\begin{array}{l}\text { Low Inflation } \\
\text { Pressure }^{6}\end{array}$ & $\begin{array}{l}\text { High Inflation } \\
\text { Pressure }^{7}\end{array}$ & $\begin{array}{l}\text { Low Inflation } \\
\text { Pressure }^{6}\end{array}$ & $\begin{array}{c}\text { High Inflation } \\
\text { Pressure }^{7}\end{array}$ \\
\hline \multirow{5}{*}{ Filled } & Tractor front ${ }^{1}$ & 11 & \multicolumn{2}{|c|}{1904} & \multicolumn{2}{|c|}{57} \\
\hline & Tractor rear ${ }^{2}$ & 46 & \multicolumn{2}{|c|}{4840} & \multicolumn{2}{|c|}{96} \\
\hline & Tanker 1st axle ${ }^{3}$ & 57 & 7445 & 4152 & 76 & 136 \\
\hline & Tanker 2nd axle ${ }^{3}$ & 56 & 7727 & 4526 & 72 & 123 \\
\hline & Tractor front & 10 & \multicolumn{2}{|c|}{1926} & \multicolumn{2}{|c|}{54} \\
\hline \multirow{3}{*}{ Half-filled } & Tractor rear & 41 & \multicolumn{2}{|c|}{4335} & \multicolumn{2}{|c|}{95} \\
\hline & Tanker 1st axle & 39 & 5112 & 3713 & 76 & 105 \\
\hline & Tanker 2nd axle & 37 & 5584 & 4029 & 66 & 91 \\
\hline \multirow{4}{*}{ Empty } & Tractor front & 13 & \multicolumn{2}{|c|}{2348} & \multicolumn{2}{|c|}{57} \\
\hline & Tractor back & 31 & \multicolumn{2}{|c|}{3691} & \multicolumn{2}{|c|}{83} \\
\hline & Tanker 1st axle & 18 & 4060 & 3652 & 45 & 50 \\
\hline & Tanker 2nd axle & 18 & 4335 & 3607 & 43 & 51 \\
\hline
\end{tabular}

${ }^{1} 540 / 65 \mathrm{R} 30,{ }^{2} 650 / 65 \mathrm{R} 42,{ }^{3} 750 / 60 \mathrm{R} 30.5,{ }^{4}$ Measured on farm's electronic weighbridge, ${ }^{5}$ Tire print was chalked and photometrically evaluated [11], ${ }^{6} 100 \mathrm{kPa},{ }^{7} 300 \mathrm{kPa}$.
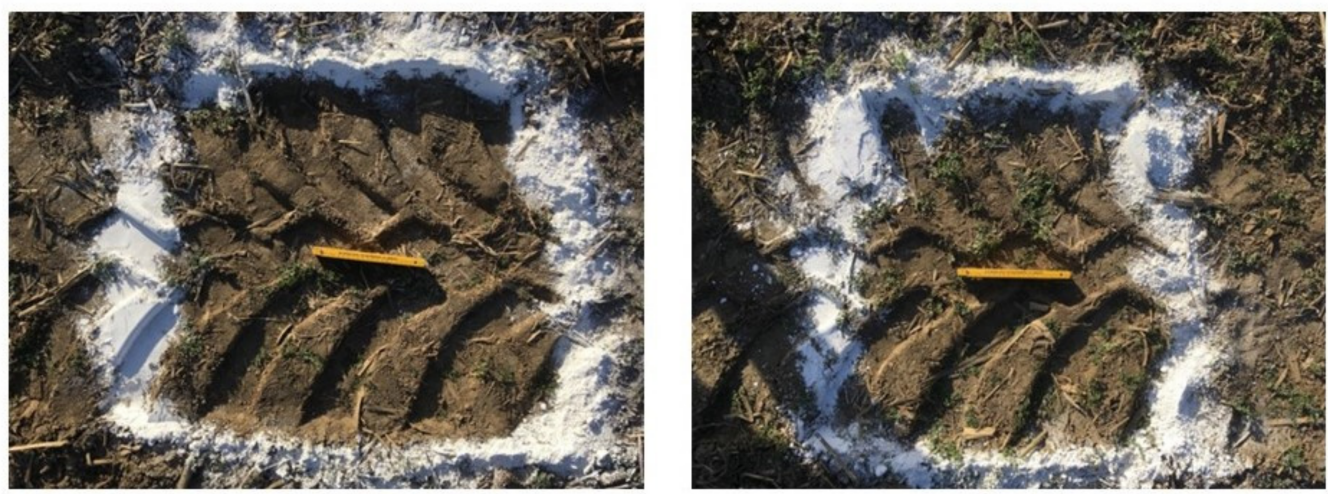

Figure 1. Tire print of a rear slurry tanker wheel at the half-filled tanker filling level with low tire inflation pressure (left) and high tire inflation pressure (right).

\subsection{Measurements}

After passing the plots with the tractor-slurry tanker combination, tire track depth and soil penetration resistance were measured. Track depth was measured five times for each tanker filling level $\times$ tire inflation pressure combination. Before measuring, the ridge on the sides of the track was levelled down to the general ground surface. Then, the vertical distance between the middle tire print and the horizontal rigid slat was measured with a ruler.

Soil penetration resistance was measured with a cone penetrometer (Eijkelkamp, The Netherlands) $\left(60^{\circ}\right.$ cone and $\left.1 \mathrm{~cm}^{2}\right)$ to a depth of $40 \mathrm{~cm}$. For each plot, five cone penetrations were recorded. In total, 360 cone penetrations were conducted during the experiment: 3 tanker filling levels (filled, half-filled, empty) $\times 2$ tire inflation pressures (high, low) $\times$ 2 ground covering (+cover crop, - cover crop) $\times 2$ traffic sets (un-wheeled: outside of the track area in the undisturbed soil, wheeled: within tracks) $\times 3$ replicates $\times 5$ cone penetration. The cone penetrations in the wheeled plots were taken from the center of the tire print.

Maize was planted with a row distance of $75 \mathrm{~cm}$ on 25 May 2018 in the tracks of the slurry tanker with a precision seeder. The marked plots were not rolled over with the wheels of the tractor during tillage, seeding, or fertilization $\left(150 \mathrm{~kg} \mathrm{ha}^{-1}\right.$ urea, $\left.46 \% \mathrm{~N}\right)$. Harvest was performed after reaching physiological maturity in 18 September 2018, where the plants from each plot were cut manually from a plant row of $2 \mathrm{~m}$. The maize cobs 
were removed from the plants and dried $24 \mathrm{~h}$ at $105^{\circ} \mathrm{C}$. Maize kernels were separated and weighed with a laboratory corn sheller (Wintersteiger LS 230, Ried, Austria).

\subsection{Statistical Analysis}

All statistical analyses were applied using IBM $^{\circledR}$ SPSS $^{\circledR}$ Statistics 21. Assumptions for analysis of variance (ANOVA) were tested with the Levene test for homogeneity of variances and the Shapiro-Wilk test for normal distribution of residuals. ANOVA tests were carried out for track depth, soil penetration resistance, and crop yield to detect the effects of tanker filling levels, tire inflation pressure, and ground covering. Statistically significant differences between means were analyzed with the Student-Newman-Keuls procedure $(p<0.05)$.

\section{Results}

The three-factorial ANOVA showed significant effects of tire inflation pressure and ground covering on the measured parameter (Table 2).

Table 2. ANOVA results of tire track depth, soil penetration resistance (averaged for each depth), and grain of maize yield.

\begin{tabular}{|c|c|c|c|c|c|c|c|}
\hline \multirow{2}{*}{ Parameter } & \multirow{2}{*}{ Unit } & \multicolumn{6}{|c|}{ ANOVA } \\
\hline & & TFL $^{a}$ & TIP $^{b}$ & $\mathrm{GC}^{\mathrm{c}}$ & TFL $\times$ TIP & TFL $\times$ GC & $\mathrm{TIP} \times \mathrm{GC}$ \\
\hline Tire track depth & $(\mathrm{cm})$ & n.s. & $* * *$ & $*$ & n.s. & n.s. & n.s. \\
\hline Penetration resistance $(0-20 \mathrm{~cm})$ & $(\mathrm{MPa})$ & n.s. & $* * *$ & $* *$ & n.s. & n.s. & n.s. \\
\hline Penetration resistance $(21-40 \mathrm{~cm})$ & $\mathrm{MPa})$ & n.s. & $* * *$ & n.s & n.s. & n.s. & n.s. \\
\hline Grain of maize yield & $\left(\mathrm{kg} \mathrm{ha}^{-1}\right)$ & n.s. & n.s. & * & n.s. & n.s. & n.s. \\
\hline
\end{tabular}

${ }^{\mathrm{a}}$ Tanker filling level, ${ }^{\mathrm{b}}$ Tire inflation pressure, ${ }^{\mathrm{c}}$ Ground cover; Significant effects: $p<0.05\left({ }^{*}\right) ; p<0.01\left({ }^{* *}\right)$, and $p<0.001\left({ }^{* * *}\right)$, n.s. $=$ not significant.

\subsection{Tire Track Depth}

Regarding all treatments, tire track depth tended to be deeper in the filled and halffilled slurry tanker setting than in the empty one (Table 3). Average tire track depth was deeper in the field with a cover crop than in the field without a cover crop $(6.88 \mathrm{~cm}$ vs. $5.83 \mathrm{~cm}, p=0.014)$. Additionally, high tire inflation pressure of the slurry tanker showed significantly deeper tire tracks in the field than with low inflation pressure $(6.68 \mathrm{~cm}$ vs. $6.03 \mathrm{~cm}, p=0.000$ ).

Table 3. Tire track depth $(\mathrm{cm})$ affected by tire inflation pressure, filling level of slurry tanker (filled, half-filled and empty), and ground covering (+cover crop, - cover crop).

\begin{tabular}{|c|c|c|c|c|c|c|c|c|c|}
\hline \multirow{2}{*}{$\begin{array}{c}\text { Tire } \\
\text { Inflation } \\
\text { Pressure }\end{array}$} & \multicolumn{3}{|c|}{ Filled Tanker } & \multicolumn{3}{|c|}{ Half-Filled Tanker } & \multicolumn{3}{|c|}{ Empty Tanker } \\
\hline & +Cover Crop & -Cover Crop & Mean & +Cover Crop & - Cover Crop & Mean & +Cover Crop & -Cover Crop & Mean \\
\hline Low & 6.20 & 5.80 & $6.00^{\mathrm{a}}$ & 6.86 & 5.83 & $6.35^{a}$ & 6.61 & 4.89 & $5.75^{\mathrm{a}}$ \\
\hline High & 7.49 & 7.11 & $7.30^{b}$ & 7.23 & 5.93 & $6.58^{b}$ & 6.88 & 5.41 & $6.15^{b}$ \\
\hline Mean & $6.85^{\mathrm{B}}$ & $6.46^{\mathrm{A}}$ & 6.65 & $7.05^{\mathrm{B}}$ & $5.88^{\mathrm{A}}$ & 6.47 & $6.75^{\mathrm{B}}$ & $5.15^{\mathrm{A}}$ & 5.95 \\
\hline
\end{tabular}

Statistically significant differences $(p<0.05)$ are shown for the cover crop effect with capital letters and for the tire inflation pressure effect with small letters.

\subsection{Soil Penetration Resistance}

Soil penetration resistance was not significantly affected by the filling level of the slurry tanker (Table 4) rather that the filled tanker tended to result in higher top soil penetration resistance than the half-filled and empty tanker. Average soil penetration resistance $(0-20 \mathrm{~cm})$ was significantly differentiated by the treatment: un-wheeled plot at $0.76 \mathrm{MPa}$, low inflation pressure at $1.17 \mathrm{MPa}$, high inflation pressure at $1.31 \mathrm{MPa}(p=0.000)$. At a soil depth of $21-40 \mathrm{~cm}$, average soil penetration resistance was significantly lower $(p=0.007)$ in the un-wheeled plot $(2.06 \mathrm{MPa})$ than in the low inflation pressure $(2.24 \mathrm{MPa})$ and high inflation pressure plots (2.26 MPa). 
Table 4. Soil penetration resistance (MPa), averaged for the depths $(0-20 \mathrm{~cm}$ and $21-41 \mathrm{~cm})$ affected by the treatment (un-wheeled, low and high inflation pressure), filling level of slurry tanker (filled, half-filled, empty), and ground covering (+cover crop, - cover crop).

\begin{tabular}{|c|c|c|c|c|c|c|c|c|c|c|}
\hline \multirow[b]{2}{*}{ Soil Depth (cm) } & \multirow[b]{2}{*}{ Treatment } & \multicolumn{2}{|c|}{ Filled Tanker } & \multirow[b]{2}{*}{ Mean } & \multicolumn{2}{|c|}{ Half-Filled Tanker } & \multicolumn{4}{|c|}{ Empty Tanker } \\
\hline & & +Cover Crop & - Cover Crop & & +Cover Crop & $\begin{array}{l}\text {-Cover } \\
\text { Crop }\end{array}$ & Mean & $\begin{array}{c}+ \text { Cover } \\
\text { Crop }\end{array}$ & $\begin{array}{l}\text {-Cover } \\
\text { Crop }\end{array}$ & Mean \\
\hline \multirow{3}{*}{$0-20$} & Un-wheeled & 0.74 & 0.67 & $0.71^{\mathrm{a}}$ & 0.70 & 0.82 & $0.76^{\mathrm{a}}$ & 0.72 & 0.81 & $0.76^{\mathrm{a}}$ \\
\hline & Low & 1.17 & 1.27 & $1.22^{b}$ & 1.11 & 1.23 & $1.17^{\mathrm{b}}$ & 1.06 & 1.21 & $1.14^{\mathrm{b}}$ \\
\hline & High & 1.30 & 1.66 & $1.48^{\mathrm{c}}$ & 1.18 & 1.32 & $1.25^{c}$ & 1.16 & 1.24 & $1.23^{c}$ \\
\hline Mean & & $1.07 \mathrm{~A}$ & $1.20^{\mathrm{B}}$ & 1.14 & $1.00 \mathrm{~A}$ & $1.12^{\mathrm{B}}$ & 1.06 & $0.98^{\mathrm{A}}$ & $1.09^{\mathrm{B}}$ & 1.03 \\
\hline \multirow{3}{*}{$21-40$} & Un-wheeled & 2.09 & 2.06 & $2.08^{a}$ & 1.88 & 1.99 & $1.94^{\mathrm{a}}$ & 1.95 & 2.24 & $2.10^{\mathrm{a}}$ \\
\hline & Low & 2.25 & 2.21 & $2.23^{b}$ & 2.21 & 2.24 & $2.23^{b}$ & 2.15 & 2.34 & $2.25^{b}$ \\
\hline & High & 2.33 & 2.32 & $2.33^{b}$ & 2.20 & 2.25 & $2.23^{b}$ & 2.30 & 2.15 & $2.23^{b}$ \\
\hline Mean & & 2.22 & 2.20 & 2.21 & 2.10 & 2.16 & 2.13 & 2.14 & 2.24 & 2.19 \\
\hline
\end{tabular}

Statistically significant differences $(p<0.05)$ are shown for the cover crop effect with capital letters and for the inflation pressure effect with small letters.

The effect of ground cover was significant at a soil depth of 0-20 cm (+cover crop: $1.01 \mathrm{MPa}$ vs. - cover crop: $1.14 \mathrm{MPa}, p=0.008)$, but not at a soil depth of $21-40 \mathrm{~cm}$ (+cover crop: $2.15 \mathrm{MPa}$ vs. - cover crop: 2.20 MPa, n.s.).

Compared to the un-wheeled, the increase in soil penetration resistance $(0-20 \mathrm{~cm})$ was lower with low tire inflation pressure than with high tire inflation pressure: $72 \%$ vs. $108 \%$ (total filled), $54 \%$ vs. $64 \%$ (half-filled), and 50\% vs. 62\% (empty). In the subsoil (21-40 cm), the effect of tire inflation pressure was much lower: $7 \%$ vs. $12 \%$ (total filled), $15 \%$ vs. $15 \%$ (half-filled), and $7 \%$ vs. $6 \%$ ).

A peak of the cone penetration could be seen in the depth $0-5 \mathrm{~cm}$ in the wheeled plots (Figure 2). A plough pan was not observed, indicating that there were no soil compaction formations left, which had been caused by the former in-furrow moldboard ploughing. Five years ago, the tillage system shifted from ploughing to reduced tillage.
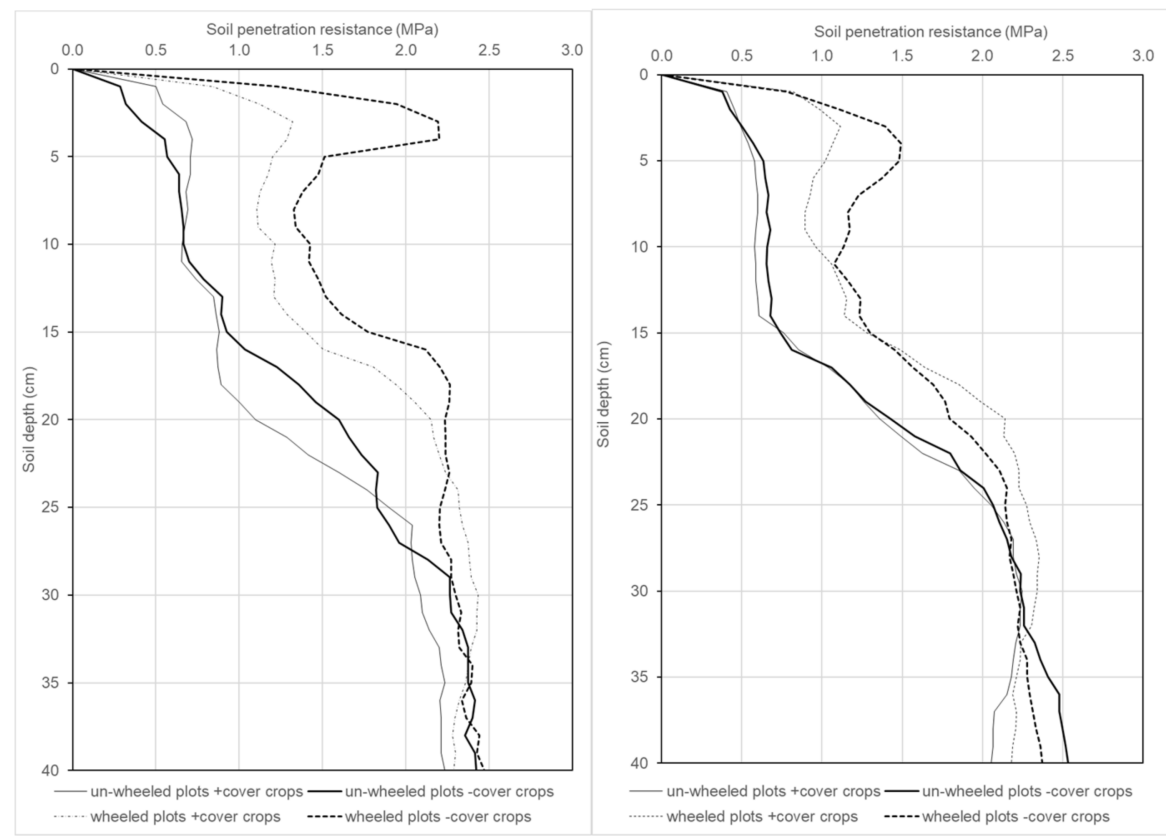

Figure 2. Soil penetration resistance (MPa) at high tire inflation pressure (left) and low tire inflation pressure (right), comparing un-wheeled plots and wheeled plots; +cover crop and -cover crop. Wheeled plots were over-rolled with the tractor-filled slurry tanker.

\subsection{Grain of Maize Yield}

Maize grain yield was not significantly affected by the filling level of the slurry tanker or tire inflation pressure (Table 5). The average maize grain yield for the un-wheeled plots 
was $9381 \mathrm{~kg} \mathrm{ha}^{-1}$, for high tire inflation pressure it was $9087 \mathrm{~kg} \mathrm{ha}^{-1}$, and for low tire inflation pressure of $9532 \mathrm{~kg} \mathrm{ha}^{-1}$. Grain of maize yield was significantly higher $(p=0.036)$ in the field +cover crop $\left(9639 \mathrm{~kg} \mathrm{ha}^{-1}\right)$ than in the field -cover crop $\left(9028 \mathrm{~kg} \mathrm{ha}^{-1}\right)$.

Table 5. Grain of maize yield ${ }^{1}\left(\mathrm{~kg} \mathrm{ha}^{-1}\right)$ affected by the treatment (un-wheeled, low and high inflation pressure), filling level of slurry tanker (filled, half-filled, empty), and ground covering (+cover crop, -cover crop).

\begin{tabular}{|c|c|c|c|c|c|c|c|c|c|}
\hline \multirow{2}{*}{ Treatment } & \multicolumn{3}{|c|}{ Filled Tanker } & \multicolumn{3}{|c|}{ Half-Filled Tanker } & \multicolumn{3}{|c|}{ Empty Tanker } \\
\hline & +Cover Crop & -Cover Crop & Mean & +Cover Crop & -Cover Crop & Mean & +Cover Crop & -Cover Crop & Mean \\
\hline Un-wheeled & 9609 & 9253 & 9431 & 9938 & 8809 & 9373 & 9967 & 8709 & 9338 \\
\hline Low & 10,516 & 9664 & 10,090 & 9218 & 9600 & 9409 & 9442 & 8751 & 9097 \\
\hline High & 8504 & 8791 & 8648 & 9362 & 8622 & 8992 & 10,193 & 9051 & 9622 \\
\hline Mean & $9543^{\text {в }}$ & $9236^{A}$ & 9390 & $9506^{\text {B }}$ & $9010^{A}$ & 9258 & $9867^{\text {в }}$ & $8837^{\mathrm{A}}$ & 9352 \\
\hline
\end{tabular}

${ }^{1} 12 \%$ moisture content; Statistically significant differences $(p<0.05)$ are shown for the cover crop effect with capital letters.

\section{Discussion}

Mean ground pressure increased with wheel load (Table 1) for both high and low tire inflation pressure. This was also confirmed by SchjØnning et al. [7]. Due to lowering the tire inflation pressure in the slurry tanker wheel, the mean soil-tire contact area increased by $75 \%$ (filled), 38\% (half-filled), and 16\% (empty tanker). This resulted in decreased contact area pressure (filled: $-43 \%$, half-filled: $-28 \%$; empty tanker: $-13 \%$ ) (Table 1 ). These technical effects directly affected physical soil parameters (tire track depth and soil penetration resistance). Mitigation of tire track depth is a key factor in lowering soil compaction and soil gully erosion by water in hilly areas. Additionally, tire tracks in the field require more fuel energy for their loosening. An increase of soil-tire contact area through lowering tire inflation pressure reduces tire track depth, which was also confirmed by Raper et al. [12]. This technically induced effect can further be enhanced by a higher soil bearing capacity, which is higher in conservation tillage systems than soil-turning systems $[13,14]$.

Wheel load is the main driver for stresses reaching deep soil layers [7,15]. In our study, we found no significant effects of the wheel loads (corresponding to tanker filling level) on average soil penetration resistance at a soil depth of $21-40 \mathrm{~cm}$. Furthermore, soil penetration resistance $(21-40 \mathrm{~cm})$ between high and low tire inflation pressure was the same, indicating that the soil was not significantly stressed in the subsoil. However, there was a significant difference between un-wheeled and wheeled plots. Contrary to this, SchjØnning et al. [7] reported higher soil resistance in the subsoil for tractor-trailer combinations than for the self-propelled slurry tanker carrying wheel loads up to $12 \mathrm{Mg}$. They explained this effect by the low tire inflation pressure of the very wide and voluminous tires (1050/50R32) of the self-propelled slurry tanker. Additionally, the single pass of the self-propelled slurry tanker also led to lower soil penetration resistance than in multiple passes of the tractor-slurry tanker combination.

Besides soil carbon enrichment and ecosystem services, cover crops have a positive effect on soil structure, which resulted in a loosened soil with lower soil penetration resistance (Table 3).

These positive effects of cover crops are linked to a higher degree of soil deformation after traffic by the tractor-slurry tanker combination. The loosened soil by cover crop created $15 \%$ deeper tire tracks than without a cover crop during traffic. According to a study by Folorunso et al. [16], cover crops reduce soil surface strength up to $41 \%$, which would explain the findings of a higher soil deformation degree after traffic. Consequently, there is a higher risk of soil gully erosion by water in sloped fields with cover crops. Through lowering tire inflation pressure, tire track depth could be reduced by $17.8 \%$ in the setting with the fully filled slurry tanker. This compensatory effect was much lower in the settings with the half-filled and the empty slurry tanker $(-3.5 \%$ and $-6.5 \%)$.

Furthermore, with increased wheel load, the effect of reduced tire inflation pressure on the soil penetration resistance $(0-20 \mathrm{~cm})$ increased. Soil penetration resistance $(0-20 \mathrm{~cm})$ was higher with high tire inflation pressure than with low tire inflation pressure. This 
indicates that lowering tire inflation pressure preserves topsoil, which is confirmed by studies $[17,18]$. Tire inflation pressure reduction at constant wheel load positively affected stress in the topsoil. However, in deeper subsoil, tire inflation pressure had no influence on soil stress [19].

A significant influence on crop yield through lowering tire inflation pressure was not found in this study. Long-term studies are necessary to evaluate the effect of 'lowinflation pressure agriculture' on crop yield. It is assumed that cover crop mixtures with different species of root mass can have an ameliorative effect on restructuring compacted soils. Mixtures of winter cover crops with tap-rooted and fibrous-rooted species provide "biological subsoil tillage" effects and can be advantageous for summer crop growth, particularly when soils are highly compacted [8].

\section{Conclusions}

The results obtained in this field experiment on passage of a tractor-slurry tanker combination with different wheel loads and tire inflation pressure show a soil protecting effect of reduced tire inflation pressure. Regarding this fact, a slurry tanker should be equipped with an automatic tire pressure controller. This would enable a lower tire inflation pressure in the field and higher tire inflation pressure on the street. Soil penetration resistance in the subsoil was higher in the wheeled treatments than in the un-wheeled control, but there were no significant effects detected caused by tire inflation pressure (high: $300 \mathrm{kPa}$, low: $100 \mathrm{kPa}$ ) and wheel load (filled, half-filled, empty slurry tanker). Cover crops created deeper track depths after traffic, which is explained by the loosening of cover crop roots. Cover crops with their positive ecological effects can reduce the risk of potential soil compaction and have ameliorative effects on restoring the soil structure.

Author Contributions: Conceptualization, G.M. and H.W.; Methodology, G.M. and H.W; Software, G.M.; Validation, G.M.; Formal analysis, G.M.; Investigation, G.M.; Resources, H.W.; Data curation, E.S. and G.M.; Writing—original draft preparation, G.M. and E.S.; Writing—review and editing, G.M. and E.S.; Visualization, G.M.; Supervision, H.W.; Project administration, H.W. All authors have read and agreed to the published version of the manuscript.

Funding: This research received no external funding.

Institutional Review Board Statement: Not applicable.

Informed Consent Statement: Not applicable.

Data Availability Statement: Data is contained within the article.

Acknowledgments: The authors thank Wolfgang Puntigam, Philipp Schwaiger, and Bernhard Stelzer for conducting the field experiments. The authors also wish to express their gratitude to Craig Jackson for proofreading. Open access funding was provided by the BOKU Vienna Open Access Publishing Fund.

Conflicts of Interest: The authors declare no conflict of interest.

\section{References}

1. Lamandé, M.; Greve, M.H.; Schjønning, P. Risk assessment of soil compaction in Europe-Rubber tracks or wheels on machinery. Catena 2018, 167, 353-362. [CrossRef]

2. Keller, T.; Sandin, M.; Colombi, T.; Horn, R.; Or, D. Historical increase in agricultural machinery weights enhanced soil stress levels and adversely affected soil functioning. Soil Tillage Res. 2019, 194, 104293. [CrossRef]

3. Molari, G.; Mattetti, M.; Walker, M. Field performance of an agricultural tractor fitted with rubber tracks on a low trafficable soil. J. Agric. Eng. 2015, 46, 162-166. [CrossRef]

4. Moitzi, G.; Amon, S.; Klik, A.; Schwen, A. Effect of two-axle and three-axle sugarbeet tanker harvester on selected soil-physical properties in dry and wet soil conditions. Agric. Eng. Int. CIGR J. 2019, 21, 18-27.

5. Moitzi, G.; Košutić, S.; Kumhála, F.; Nozdrovicky, L.; Martinov, M.; Gronauer, A. Machinery induced compaction of agricultural soil and mitigation strategies in the Danube Region. In Proceedings of the 44th International Symposium on Agricultural Engineering-Actual Tasks on Agricultural Engineering, Opatija, Croatia, 23-26 February 2016; Sveučilište u Zagrebu, Agronomski fakultet, Zavod za mehanizaciju poljoprivrede, Svetošimunska 25: Zagreb, Croatia, 2016; pp. 15-35, ISBN $1848-4425$. 
6. Ren, L.; D’Hose, T.; Ruysschaert, G.; de Pue, J.; Meftah, R.; Cnudde, V.; Cornelis, W.M. Effects of soil wetness and tyre pressure on soil physical quality and maize growth by a slurry spreader system. Soil Tillage Res. 2019, 195, 104344. [CrossRef]

7. Schjønning, P.; Lamandé, M.; Munkholm, L.J.; Lyngvig, H.S.; Nielsen, J.A. Soil precompression stress, penetration resistance and crop yields in relation to differently-trafficked, temperate-region sandy loam soils. Soil Tillage Res. 2016, 163, 298-308. [CrossRef]

8. Chen, G.; Weil, R.R.; Hill, R.L. Effects of compaction and cover crops on soil least limiting water range and air permeability. Soil Tillage Res. 2014, 136, 61-69. [CrossRef]

9. Chen, G.; Weil, R.R. Root growth and yield of maize as affected by soil compaction and cover crops. Soil Tillage Res. 2011, 117, 17-27. [CrossRef]

10. ZAMG. Klima/Klimaübersichten/Jahrbuch. Available online: https://www.zamg.ac.at/cms/de/klima/klimauebersichten/ jahrbuch (accessed on 14 May 2021).

11. Diserens, E.; Alaoui, A. Contact Area of Agricultural Tyres, Estimation. In Encyclopedia of Agrophysics; Gliński, J., Horabik, J., Lipiec, J., Eds.; Springer Science + Business Media B.V: Dordrecht, The Netherlands, 2011; pp. 148-153; ISBN 978-90-481-3584-4.

12. Raper, R.L.; Bailey, A.C.; Burt, E.C.; Way, T.R.; Liberati, P. The effects of reduced inflation pressure on soil-tire interface stresses and soil strength. J. Terramechanics 1995, 32, 43-51. [CrossRef]

13. Brunotte, J. Konservierende Bodenbearbeitung als Beitrag zur Minderung von Bodenschadverdichtungen, Bodenerosion, Run off und Mykotoxinbildung im Getreide; Humboldt-Universität zu Berlin: Berlin, Germany, 2007.

14. Moitzi, G.; Wagentristl, H.; Liebhard, P.; Neugschwandtner, R. Influence of tillage systems in a long-term experiment on track depths and crop yields under Pannonian climate. In IX International Scientific Symposium Farm Machinery; Department of Machinery Exploitation and Management of Production Processes, University of Life Sciences in Lublin: Lublin, Poland, 2017; pp. 250-254.

15. Arvidsson, J.; Keller, T. Soil stress as affected by wheel load and tyre inflation pressure. Soil Tillage Res. 2007, 96, 284-291. [CrossRef]

16. Folorunso, O.A.; Rolston, D.; Prichard, P.T.; Louie, D.T. Cover crops lower soil surface strength, may improve soil permeability. Calif. Agric. 1992, 46, 26-27. [CrossRef]

17. Söhne, W. Some Basic Considerations of Soil Mechanics as Applied to Agricultural Engineering; National Inst. of Agricultural Engineering: Silsoe, UK, 1958.

18. He, R.; Sandu, C.; Shenvi, M.N.; Mousavi, H.; Carrillo, J.; Osorio, J.E. Laboratory experimental study of tire tractive performance on soft soil: Towing mode, traction mode, and multi-pass effect. J. Terramechanics 2021, 95, 33-58. [CrossRef]

19. Keller, T.; Arvidsson, J. Technical solutions to reduce the risk of subsoil compaction: Effects of dual wheels, tandem wheels and tyre inflation pressure on stress propagation in soil. Soil Tillage Res. 2004, 79, 191-205. [CrossRef] 